Bjelke, B., W. (2017). Læreplananalyse ved fag/svenneprøven, forankret i arbeidslivets

kompetansekrav. Scandinavian Journal of Vocations in Development

http://dx.doi.org/10.7577/sjvd.2009

Peer reviewed article

Fagfellevurdert artikkel

\title{
Læreplananalyse ved fag-/svenneprøven, forankret i arbeidslivets kompetansekrav
}

Forfatter:

Bjørn Wilhelm Bjelke

Bwbjelke

yrkespedagogisk rådgiver

bjelke@qxz.no

Nøkkelord: fag-/svenneprøver, læreplananalyse, yrkesfag, yrkeskompetanse, 


\section{Sammendrag}

Bakgrunnen for studien er at Læreplanene i yrkesfag kan oppfattes som uklare som kan resultere i ulikt innhold og ulik grad av relevans i samme yrkesutdanning, og dermed gi manglende validitet i fag- og svenneprøver.

Artikkelen belyser hva yrkeskompetanse kan være og hvilke kompetanseelementer ulike yrker har til felles. Den belyser også hvordan kompetanseelementer i læreplanen, som er relevante å prøve til fag- og svenneprøven, kan identifiseres og dermed sikre validitet i prøvene i forhold til yrkenes reelle kompetansebehov.

Den teoretiske forankringen til denne studien er knyttet til innholdet i begrepene yrkeskompetanse, vurdering og læreplananalyse og støtter seg blant annet til Goodlads og Engelsens perspektiv på læreplananalyse.

Studien hadde en hermeneutisk forskningstilnærming. Metodene som ble brukt i studien var kvalitative intervjuer av fem yrkesutøvere i fem ulike yrker og dokumentanalyse av læreplaner for bedrift/Vg3 i respondentenes yrker.

Intervjuene belyser hva yrkeskompetanse er i de ulike yrkene. Funn fra intervjuene kategoriseres og presenteres i form av et verktøy for analyse av læreplaner, som respondentene prøvde ut gjennom analyse av læreplanene for det lærefaget de selv har kompetanse i.

Resultatet av studien viser felles kompetanseelementer for ulike yrker. Studien indikerer også manglende samsvar mellom innholdet i læreplanene og kompetansekravet i arbeidslivet, samt behov for videre forskning på analyse av kompetanser og kompetansebeskrivelse. Resultatet av studien er et verktøy for analyse av læreplaner. 


\section{Abstract}

The reason for the study was that the Curricula in vocational subjects could be regarded as unclear and that this could have the effect that the content and degree of relevance of the same vocational training program may vary. It may also result in a lack of validity in qualifying examinations and apprentices’ final examinations.

The article discusses what vocational competence may consist of and which competence elements different crafts and vocations have in common. The article also highlights how to identify competence elements in the curriculum which it is relevant to include as test elements in the qualifying examinations and the apprentices' final examinations to ensure the validity of the examinations in relation to the actual competence requirements in the crafts and vocations in question.

Den teoretiske forankringen til denne studien er knyttet til innholdet i begrepene yrkeskompetanse, vurdering og læreplananalyse og støtter seg blant annet til Goodlads og Engelsens perspektiv på læreplananalyse.

The theoretical basement for the study presented in this article, is related to Goodlads and Engelsens perspective of the concepts vocational competence, evaluation and curriculum analysis.

The study was based on a hermeneutic research approach. The methods used in the study were qualitative interviews of five respondents engaged in different crafts and vocations as well as a document analysis of curricula for apprenticeships in enterprises/Upper secondary level 3 (Vg3) in the respondents' crafts and vocations.

The interviews show what vocational competence is in the various crafts and vocations. The findings from the interviews have been categorized and presented in the form of a tool for analysis of curricula, which the respondents tested through an analysis of the curricula for the craft or vocation in which they themselves have acquired competence.

The study defines joint competence elements for different crafts and vocations. It also points out that there is a mismatch between the content of the curricula and the competence requirements in working life as well as a need for further research into competence analysis and competence description. The findings of the study constitute a tool for analysis of curricula.

Key words: journeyman's examinations, curriculum analysis, vocational, vocational qualifications 


\section{Innledning}

Læreplaner i yrkesfag kan oppleves som uklare i forhold til hva som er målet for opplæringen. Uklarheter kan føre til lite relevant vurdering av elever, lærlinger og praksiskandidater ved fag-/svenneprøven (Deichman-Sørensen et al., 2011; Utdanningsdirektoratet (Udir), 2008). Studier viser at gjennomføring av fag-/svenneprøver er problematisk. Det rapporteres om uklarheter i hvordan prøvenemndene ivaretar flere sentrale aspekt ved kompetansekravene etter læreplanverket i Kunnskapsløftet. Det fremkommer at planlegging, vurdering og dokumentasjon har en svak plass i fag-/svenneprøven. Eksplisitt nevnes fare for at kompetanseelementer om dokumentasjon til dels er fraværende. Også sentrale kunnskapsområder faller ut. Videre nevnes at prøving av kandidatens begrepsforståelse kan synes svak i fag-/svenneprøven. Det synes ikke som kompetansegivende tiltak har påvirket prøvenemndene nevneverdig (Bjelke, 1996, Deichman-Sørensen et al., 2011; Udir 2008). Mange lærebedrifter finner ikke nytte i å bruke læreplanverket (Riksrevisjonen, 2013). Det er derfor behov for å studere læreplanenes funksjon i forhold til yrkenes kompetansebehov, som grunnlag for å finne fram til aktuelle tiltak på området.

Problemstillingen for denne studien er «Hvordan kan vi identifisere kompetanseelementer i læreplanene som er relevante å prøve til fag-/svenneprøven?»

Denne studien bygger videre på to tidligere studier om dette emnet. Den første studiens problemstilling var «Hvordan er kvalitetsutvikling som arbeidsprosess et kompetansekrav for å bli fagarbeidere etter læreplanverket i Kunnskapsløftet?»1. Den andre studiens problemstilling var «Hva kan kjennetegne ulike kompetansenivåer hos yrkesutøvere?» (Bjelke, 2012). Resultatet fra disse to studiene var blant annet utvikling av forløperen til det analyseverktøyet som ble videreutviklet gjennom denne studien. Denne studien har fokus på identifisering av relevante kompetanseelementer i læreplanene som skal sikre relevans i vurderingen ved fag-/svenneprøven.

1 Bjelke, B. W. (2010). Læreplananalyse - Hvordan er kvalitetsutvikling som arbeidsprosess et kompetansekrav for å bli fagarbeider etter læreplanverket i Kunnskapsløftet. Kjeller: Høgskolen i Akershus. 


\section{Begrepsavklaringer}

Den teoretiske forankringen til denne studien er knyttet til innholdet i begrepene yrkeskompetanse, vurdering og læreplananalyse.

\section{Yrkeskompetanse}

Målet for opplæring i yrkesfag er at eleven/lærlingen skal utvikle yrkeskompetanse i tråd med arbeidslivets og det spesifikke yrkets behov gjennom å nå kompetansemålene i læreplanene. Kompetanse kan operasjonaliseres på mange forskjellige måter og handler om å dekomponere og generalisere begreper. Den mest kjente og innarbeidede operasjonaliseringen av kompetansebegrepet i Norge er kanskje at kompetanse består av kunnskaper, ferdigheter og holdninger. En nyere operasjonalisering er evnen til å mestre komplekse utfordringer. Denne operasjonaliseringen har vi fra The Organisation for Economic Co-operation and Development - OECDs prosjekt Definition and Selection of Competencies DeSeCo. Andre operasjonaliseringer omfatter evnen til å anvende kunnskaper og ferdigheter til å løse utfordringer (Kirke-, utdannings- og forskningsdepartementet (KUF) 1993; St.meld. nr. 30 (2003-2004), 2004). I nyere tid har det såkalte Ludvigsenutvalget operasjonalisert kompetanse på sin måte, med forskjellige ønsker om endringer for grunnopplæringen, for å møte framtidens kompetansebehov. Blant annet har Ludvigsenutvalget trukket fram kompetanseelementer som å lære å lære/metakognisjon som viktig. Disse elementene er nærmere dekomponert i denne studien og navnsatt som «kvalitetsutvikling som arbeidsprosess» (NOU 2014:7; NOU, 2015:8).

I læreplaner for fag fastsetter Kunnskapsdepartementet (KD) og Utdanningsdirektoratet nasjonale politiske vedtak om hvordan kompetanse skal operasjonaliseres, og hvilken deler av kompetansen som skal være grunnlaget for vurderingen.

Utdanningsdirektoratet benytter en definisjon på kompetanse som omfatter oppgaver og komplekse utfordringer eleven skal løse i ulike situasjoner, og ferdigheter og kunnskaper som skal kunne anvendes i konkrete situasjoner (Udir, 2005; 2011). I retningslinjer for vurdering av fag- svenneprøver operasjonaliseres kompetanse til å ha evne til å planlegge, begrunne, gjennomføre, vurdere og dokumentere arbeidsoppgaver (Forskrift til opplæringslova, 2006; KUF, 1997; Nasjonalt læremiddelsenter, 1998). Vi finner også denne dimensjonen fra retningslinjene sporadisk implementert i læreplaner for fag (Udir, 2017). Relasjonene mellom 
disse perspektivene på kompetanse kan oppleves uklar i lys av andre aktører og forskeres bruk av begrepene ( Hårstad, 2009; Large, 2001; Sund, 2005; Udir, 2010; 2015).

Lokalt i fylkeskommunene og lærebedriftene operasjonaliseres læreplanenes kompetansebeskrivelse ytterligere gjennom lokalt læreplanarbeid. Begrunnelsen for mindre detaljert statlig operasjonalisering av kompetansekravet i læreplanene, kan være at reformer ikke skulle være kostnadsdrivende (Nore, 2008). Myndighetene står i et dilemma mellom hensynet til den enkelte elevs behov på den ene side, og samfunnets interesser ved valg av lærestoff i opplæringen på den annen side (Monsen, 2004). De ulike aktørene som forvalter læreplaner, utvikler gjennom fortolkninger sin egen forståelse av hva kompetansekravet i læreplanene uttrykker, og derved operasjonaliserer dem på ulike måter.

Disse ulike tilnærmingene til å operasjonalisere kompetansebegrepet, ga behov for å studere begrepet nærmere2 (Bjelke, 2012). Operasjonaliseringen av begrepet kompetanse tok utgangspunkt i og ble generert fra arbeidslivets kompetansebehov (Sannerud, 2006). Yrkeskompetanse ble etter disse studiene operasjonalisert til å bety evne til å planlegge, gjennomføre, vurdere og dokumentere løsning av arbeidsoppgaver ved anvendelse av kunnskapsområder: ferdigheter, kunnskaper og kontroll over ytre betingelser (Bjelke, 2012).

Evnen til å planlegge, begrunne, gjennomføre, vurdere og dokumentere løsning av arbeidsoppgaver er anerkjente allmenne krav til yrkesutøvelse (Dale \&Wærnes, 2003; Havnen \& Buland, 2003; Sund, 2005; Universitetet i Bergen (UiB), 2013; Udir, 2006; Fonn, 2009). Det er arbeidsoppgavene som kjennetegner et yrke og som skiller det fra andre yrker. Arbeidsoppgavene konstituerer yrket/lærefaget.

Kontroll over ytre betingelser er en underkategori i kompetansebegrepet som er lite kjent. Det handler om den delen av ressursene i kompetansen som ikke er fagarbeiderens kunnskaper eller ferdigheter. Kontroll over ytre betingelser er andre faktorer som fremmer mulighetene for å utøve fagarbeid, og som fagarbeideren må tilegne seg, for eksempel privat utstyr, tid,

2 Bjelke, B. W. (2010). Læreplananalyse - Hvordan er kvalitetsutvikling som arbeidsprosess et kompetansekrav for å bli fagarbeider etter læreplanverket i Kunnskapsløftet. Kjeller: Høgskolen i Akershus. 
rettigheter osv. (Bjelke, 2012; Skårderud, Fauske, Nygren, Nilsen \& Kollestad, 2005; Nygren, 2004).

Denne operasjonaliseringen av kompetanse fra tidligere studier, var utgangspunktet for den studien som rapporteres her.

Kunnskaper og ferdigheter brukes i planlegging, gjennomføring og vurdering av alternative løsninger til arbeidsoppgaver i arbeidslivet og til fag-/svenneprøven. Til dokumentasjonen trenger vi begreper og symboler for disse fenomenene for å kommunisere dem. Teoretiske ferdigheter er blant de ressurser yrkesutøveren skal bruke til å løse arbeidsoppgaver. Således omfattes teori av kompetanse slik begrepet kompetanse er operasjonalisert i denne studien.

\section{Vurdering}

Utfordringene i arbeidet med vurdering til fag-/svenneprøven, som i yrkesopplæringen generelt, er blant annet målene om å gjøre vurderingen både legitim, legal og rasjonell. Det legitime er ikke nødvendigvis legalt og rasjonelt. Det legale er ikke nødvendigvis rasjonelt og legitimt. Det rasjonelle er ikke nødvendigvis legitimt og legalt. Disse aspektene utgjør et trilemma (dilemma) i arbeidet med vurdering av yrkeskompetanse.

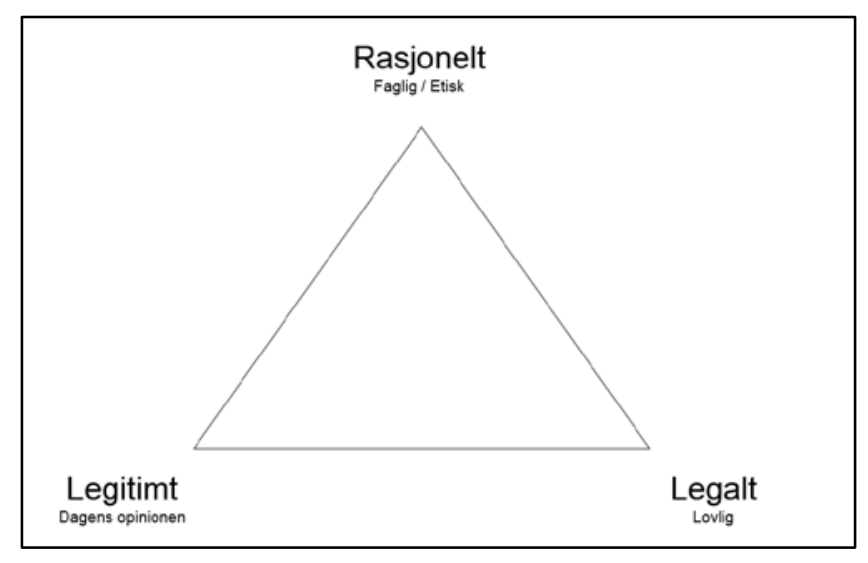

Figur 1 Trilemma

Vurdering i yrkesopplæringen, i tråd med Opplæringslova, kan sammenlignes med generelle studier. Heri er fag-/svenneprøven en studie av kvalitet på faglig arbeid og på kandidatens yrkeskompetanse. Derfor er generell kompetanse innen forskning/studier nødvendig for å gjennomføre vurderinger i yrkesopplæringen med høy kvalitet, og for å kunne vurdere kvaliteten på slike vurderinger/studier (Forskrift til opplæringslova, 2006; Grønmo, 2016). 
For å gjennomføre, forstå og forklare hva vurdering er, og å vurdere hvilken kvalitet en vurdering har, kan begreper fra generell vitenskapelig metode benyttes. Begrepene fra generell vitenskapelig metode blir et metaspråk i vurderingskompetansen. Et språk som er holdbart i skiftende politiske tider og landskap. Det legges her til grunn at vurdering i yrkesopplæringen er synonymt med en sammenlignende/ komparativ studie. Vurderingen er en sammenligning av kompetansebeskrivelsen i læreplan for fag, med lærlingens kompetanse. Studien/vurderingen har altså til hensikt å produsere kunnskap om lærlingens kompetanse. Formålet med vurderingen til fag-/svenneprøven er å gi informasjon om elevens/lærlingens yrkeskompetanse, som grunnlag for å sortere kandidater for inntak til videre studier og arbeidsliv. Vurderingen skal vise hvordan elevens/lærlingens kompetanse samsvarer med læreplanenes kompetansemål.

Metodene i vurdering av kandidatens kompetanse kan være observasjoner, samtaler og analyser av utførte arbeidsoppgaver av ulike slag. Metodetriangulering brukes for å sikre validitet og kvalitet på studien/vurderingen. Kvalitet betyr i denne sammenheng forståelse for kandidatens kompetanse i forhold til læreplanenes målbeskrivelser.

\section{Læreplananalyse}

Med inspirasjon fra Goodlad (1979) beskriver Engelsen (2003) ulike faser i læreplanutvikling og læreplanforvaltning ved implementering av mål for kompetanse i opplæringen. Disse fasene kan benyttes i beskrivelse av hva som er analyseenheten ved vurdering av læreplanverket. Engelsen beskriver flere faser/analyseenheter i implementeringen, som strekker seg fra ideene om mål for opplæringen, til hva elevene faktisk erfarer på skolen, eller i lærebedriften som er den mest aktuelle læringsarena i denne studien. Mellom ideenes læreplan og den erfarte læreplan beskriver Engelsen den formelle fastsatte læreplanen, den oppfattede læreplanen i undervisningssituasjonen og den operasjonaliserte læreplanen i form av fag-/svenneprøven. I denne studien er analyseenheten den formelle læreplanen som operasjonaliseres på en måte som skal sikre valide fag-/svenneprøver i tråd med både innholdet i læreplanene (Engelsen, 2003; Goodlad,1979) og det reelle kompetansebehovet i yrkene. 


\section{Metode}

Studien har en hermeneutisk forskningstilnærming. Metodene som er brukt er kvalitative intervjuer av fem yrkesutøvere og dokumentanalyse av læreplaner. Funn fra intervjuene presenteres i form av et verktøy for læreplananalyse og valideres gjennom utprøving av dette verktøyet.

Studien kan sies å være eksplorativ og analytisk beskrivende i den forstand at den oppdager og beskriver viktige variabler som bidrar til å identifisere kompetanseelementer i læreplanene som er relevante å prøve til fag-/svenneprøven (Grønmo, 2016; Halvorsen, 2008).

Som studerende på et fenomen man selv er en del av, er ikke forskeren bare en observatør av fenomenet, men også deltager med den grad av subjektivitet det innebærer (Skjervheim, 1996). Respondentene og fagfeller har derfor hatt et avgjørende bidrag i studien med å aktørog kollegavalidere analysene.

\section{Generalisering}

Studiens resultat, med et analyseverktøys gyldighet for hele analyseenheten, er basert på resonnementer og/eller gjenkjennelse. Studiens generalisering er derfor teoretisk/analytisk, og utvalg av undersøkelsesenheter ble gjort med denne type generalisering som formål.

Undersøkelsesenhetene ble valgt strategisk. Utvalgsstørrelsen var ikke bestemt på forhånd, da det var vanskelig å forutse hvor mange respondenter det var behov for, for å belyse problemstillingen. Funn underveis var avgjørende for valg av antall respondenter. Et mindre utvalg kilder ble valgt for å kunne gå dypere kvalitativt inn i problemfeltet som belyses (Grønmo, 2016; Ryen, 2002).

\section{Litteratursøk}

Litteraturen som er benyttet i analyse av teori om kompetanse er valgt ut strategisk fra litteraturlister i annen forskning og offentlige nasjonale utredninger. Det er tatt utgangspunkt i aktuelle dokumenter som det er referert til i samfunnsdebatten om temaet (strategisk) og som er tilgjengelig (slumpmessig), heri norske offentlige utredninger - NOU-er og stortingsmeldinger. Litteraturen er valgt ut ved strategisk slumpmessig utvelging (Grønmo, 2016). Det ble også gjennomført strukturert litteratursøk i databasene Erica og Oria med søkeordet «curriculum» som har ledet til litteratur som det er referert til i studien. 


\section{Kvalitative intervjuer}

Yrkesutøvernes beskrivelse og erkjennelse av arbeidsoppgaver og kompetansebehov i eget yrke, utgjorde en viktig del av empirien i denne studien. Derfor ble kvalitative, individuelle intervjuer valgt som metode. Deres fortellinger om arbeidsoppgaver og kompetanse i yrkene skulle ligge til grunn for tolkning av læreplanene og identifisering av relevant innhold til fagog svenneprøver. Intervjuene ble gjennomført i perioden 2013 - 2015 som interaktive samtaler hvor meninger ble dannet. Intervjuene var en faglig samtale med respondentene i deres opplevelsesverden før samtalen ble gitt en analytisk forklaring og beskrivelse. Både intervjuer og respondent var dermed deltakere i den mening som ble dannet i samtalen. For å sikre størst mulig grad av autentiske data, ble det åpenbare asymmetriske maktforholdet, som uansett er mellom intervjuer og respondent, forsøkt dempet. (Halvorsen, 2008; Kvale, Brinkmann, Anderssen, \& Rygge, 2015).

Utvalget av respondenter til intervju var begrunnet $\mathrm{i}$ at målet var utprøving og begrepsutvikling av yrkeskompetanse som analyseredskap. Det ble derfor gjennomført et strategisk kvoteutvalg for å dekke behovet for metning i datagrunnlag for å svare på problemstillingen (Grønmo, 2016). Kriterier for utvalg av respondenter var blant annet variasjon i deres faglige bakgrunn. Et annet sentralt kriterium var at dataene skulle være relevante og autentiske. Derfor ble det valgt respondenter som ikke hadde blitt formet i for stor grad av utdanningsmyndighetenes normerende informasjonsarbeid. Det var ønskelig at erfaringer fra deres aktive yrkeshverdag skulle ligge til grunn for innholdet i intervjuet. Fem yrkesutøvere med forskjellige fag-/svennebrev, som også måtte forholde seg til læreplaner i sitt arbeid med yrkesopplæring, ble valgt ut som respondenter. Yrkesutøverne hadde bakgrunn fra tømrerfaget, anleggsmaskinførerfaget, frisørfaget, blomsterdekoratørfaget og trebåtbyggerfaget. Tilgjengeligheten var også avgjørende for utvalget. Derfor er det en grad av tilfeldighet i utvalget.

Balansen mellom den totale åpenhet for respondentens livsverden og den struktur som ligger i forberedelsene, gjør at intervjuene i denne studien kan betraktes som halvstrukturerte. Underveis i datainnsamlingen er det, på bakgrunn av funn, gjort endringer i intervjuformen som gir noe ulik struktur på intervjuene (Kvale et al., 2015). Intervjuene tok utgangspunkt i arbeidstakernes arbeidsoppgaver og deres eget begrepsapparat. 


\section{Dokumentanalyse}

Analyse av læreplaner er analyse av politiske, autoritative og normative tekster. Dokumentene er mye bearbeidet gjennom læreplangrupper og intern saksbehandling hos myndighetene før og etter høringer. De er forskrifter til Opplæringslova. Prosessen med å utvikle dem, gjør dem i en viss grad til konsensusdokumenter. I dokumentene vil det være politiske kompromisser. Dokumenter kan i noen grad være enklere å analysere enn data fra intervju fordi det ikke foregår en sårbar interaksjon mellom den som samler inn dataene og kildene. Arbeidet kan lett startes, avbrytes og gjentas uten at dette er kostnadsdrivende eller at det krever innsats av andre involverte som kan være begrensende for arbeidets kvalitet. Dokumentene er dessuten tilgjengelig 24 timer i døgnet, hvilket ikke respondenter er. Tidsperioden for studien er fiksert ved dokumentanalyse (Ryen, 2002).

Ved dokumentanalyse vil dokumentene være skrevet for et annet formål enn for det forskningsarbeidet hvor tekstene brukes. I denne studiens dokumenter, er dokumentene tilgjengelig for allmennheten og utgjør sekundærdokumenter. Dokumenter er språk som er fiksert i tekst og tid. I denne studien har tekst en smal definisjon som verbalspråklig tekst, og ikke en utvidet multimodal definisjon (Lynggaard, 2010; Thagaard, 2002).

Utvalget av læreplaner ble gjort på bakgrunn av den fagbakgrunn de utvalgte respondentene hadde. Ved utvalg av læreplaner ble det benyttet strategisk kvoteutvalg, som for utvalget av respondenter. Det var med andre ord en grad av tilfeldighet i utvalget. Det betyr at det var læreplaner i tømrerfaget, anleggsmaskinførerfaget, frisørfaget, blomsterdekoratørfaget og trebåtbyggerfaget som ble analysert. For å sikre at analysen av hver enkelt læreplan var av høy kvalitet, ble analysen presentert for- og drøftet med de andre respondentene. For læreplanen i tømrerfaget, som er brukt som eksempel i denne artikkelen, er analyseresultatene drøftet med tre andre fagpersoner som utgjorde en kontrollgruppe.

Metoden for dokumentanalysen konkretiseres videre sammen med resultatene under overskriften Analyse, resultater og diskusjon.

\section{Analyse}

Data fra forskningsarbeidet ble analysert i kategorier som delvis var bestemt på forhånd, og som delvis framstod som resultat av dokumentanalysen (Lynggaard 2010), funn fra intervjuene og respondentenes beskrivelse av arbeidsoppgaver og kompetansebehov i sin 
daglige yrkesutøvelse. De forhåndsbestemte kategoriene, som var resultat av tidligere studier3 (Bjelke, 2012) var «arbeidsoppgaver», «kunnskapsområder» bestående av «kunnskaper», «ferdigheter» og «kontroll over ytre betingelser», og «kvalitetsutvikling som arbeidsprosess» bestående av «planlegging», «gjennomføring», «vurdering» og «dokumentasjon». Etter intervjuene og dokumentanalysene i denne studien ble disse kategoriene delvis endret i navn og innhold.

De samlede analysekategoriene i denne studie ble:

- Arbeidsoppgaver

o Oppgavene

o Konteksten arbeidsoppgavene står i

- Ressurser

o Ferdigheter

o Kunnskaper

o Andre ressurser - kontroll over ytre betingelser

- Kvalitetsutvikling som arbeidsprosess

o Planlegge utføring av arbeidsoppgaver

o Dokumentere planleggingen

o Gjennomføre planene

o Dokumentere gjennomføringen

o Vurdere gjennomføringen av arbeidsoppgaver

o Dokumentere vurderingen

Resultatene av analysen blir presentert i form av matriser og tabeller fordi materiale er ganske omfangsrikt og ellers ville være vanskelig å danne seg et inntrykk av (Lynggaard, 2010)

3 Bjelke, B. W. (2010). Læreplananalyse - Hvordan er kvalitetsutvikling som arbeidsprosess et kompetansekrav for å bli fagarbeider etter læreplanverket i Kunnskapsløftet. Kjeller: Høgskolen i Akershus. 


\section{Analyse, resultater og diskusjon}

Her presenteres funn fra intervjuene, som til slutt oppsummeres i form av et verktøy for læreplananalyse. Deretter presenteres funn fra læreplananalysen.

Kategoriene som dataene ble analysert i forhold til, ble strukturert og presentert i form av et verktøy for læreplananalyse og brukt i respondentenes arbeid med læreplananalysen. Verktøyet bestod dermed av et sett begreper som til sammen operasjonaliserte kompetansebegrepet i yrkesfag, basert på funn fra intervjuene med ulike fagarbeidere. Begrepene utgjorde dimensjoner og underkategorier i kompetansen, og relasjonen mellom disse elementene. Respondentene analyserte læreplanene for de lærefagene de selv har kompetanse i.

\section{Analyse av funn fra intervjuene}

Analysen viste at det var mest hensiktsmessig for respondentene å starte med identifisering av «arbeidsoppgavene» som skiller et yrke fra andre yrker (Liljeström, 1979; Wadel, 2007), og deretter hvilke spesifikke ressurser som skulle anvendes for å løse arbeidsoppgavene.

Videre viste studien gjennom drøfting av begrepet «kontroll over ytre betingelser», at «konteksten arbeidsoppgave står i», er avgjørende for å avklare en yrkesutøvers forutsetninger til å løse utfordringene og dermed at «kontroll over ytre betingelser» er en viktig del av fagarbeidernes yrkeskompetanse. «Konteksten arbeidsoppgave står i», må kanskje derfor eksplisitt nevnes som en underkategori til «arbeidsoppgaver», som en dimensjon i yrkeskompetansen. «Konteksten arbeidsoppgavene står i» blir i dag ofte betegnet som rammefaktorer (Bjørndal \& Lieberg, 1979; Hiim \& Hippe, 1989) uten at den relateres til yrkesutøverens kompetansebehov.

De aller fleste andre definisjoner og dekomponeringer av kompetanse, beskriver ikke evne til å håndtere den konteksten det kreves at arbeidsoppgavene skal kunne løses i (KUF 1993; NOU, 2015:8; St.meld. nr. 30 (2003-2004), 2004). Dette ble trukket fram av respondentene som sentralt.

Studien viste gjennom intervjuene, dokumentanalysen og drøfting at det var logiske brister i den opprinnelige operasjonalisering av kompetansebegrepet. Det viste seg også at enkelte begreper ble for lite konkret for respondentene og derfor ble operasjonaliseringen av kompetansebegrepet revidert. 
På bakgrunn av funnene, operasjonaliseres kompetanse i yrkesfag etter denne studien som:

Evnen til å planlegge, gjennomføre og vurdere løsning av arbeidsoppgaver ved anvendelse av ressurser, og å dokumentere denne prosessen.

Kompetanse i yrkesfag er i denne studien bygget opp med følgende tre hoveddimensjoner: «Arbeidsoppgaver», «ressurser» og «kvalitetsutvikling som arbeidsprosess».

\section{Arbeidsoppgaver}

Under hovedkategori «arbeidsoppgaver», resulterte analysen i to underkategorier:

«Oppgavene» og «konteksten arbeidsoppgavene står i».

I retningslinjer for læreplanarbeid kan man identifisere dimensjonen «arbeidsoppgaver» som oppgaver og komplekse utfordringer eleven skal løse i ulike situasjoner (Udir, 2005, 2011).

«Oppgaven» kan i tømrerfaget være å bygge garasjer. «Konteksten oppgaven står i» beskriver under hvilke forhold garasjebyggingen leveres i. For eksempel vil det som en respondent sier «(...) være forskjell på å bygge en garasje prefabrikkert i et industrilokale, og det å bygge opp garasjen på kundens boligtomt ute i en høststorm». Løsning av arbeidsoppgaver med mindre grad av kompleksitet, er i denne studien «ferdigheter»/ «kunnskaper» for en arbeidstaker på høyere nivå. Yrket krever ifølge respondentene kompetanse og evne til å håndtere utfordringer med større kompleksitet. En respondent sier: «For eksempel vil det å fylle en veggkonstruksjon i garasjen med isolasjon, være en kompleks arbeidsoppgave for en hjelpearbeider, mens det for en fagarbeider er en av flere ferdigheter som anvendes ved oppføring av en garasje». Oppføring av garasje er en mer kompleks utfordring.

Hjelpearbeideren leverer deljobber til garasjen, mens yrkesutøveren kan levere hele garasjen; planlegge, begrunne, gjennomføre, vurdere kvalitet på og dokumentere hele arbeidet i gitte kontekster. På denne måten kan forskjeller mellom kompetanse til å håndtere komplekse «arbeidsoppgaver» og «ferdigheter»/«kunnskaper» identifiseres og defineres. Forholdet 
mellom «ferdigheter»/«kunnskaper» og «arbeidsoppgaver» er ikke konstant, men relativt og avhenger av den enkelte persons forutsetninger og fagets egenart4 (Bjelke, 2012).

\section{$\underline{\text { Ressurser }}$}

Analysen resulterte i tre underkategorier under den andre av kompetansebegrepets hoveddimensjon; «ressurser». Disse underkategoriene er «ferdigheter», «kunnskaper» og «kontroll over ytre betingelser».

Ressursene er de «ferdigheter», «kunnskaper» og den «kontroll over ytre betingelser» som fagarbeideren må ha og kunne anvende for å løse «arbeidsoppgavene». «Ressursene» skiller seg fra «arbeidsoppgavene» ved at de ikke er produkter eller tjenester som yrkesutøveren kjennetegnes av å levere. «Ressurser» kjennetegnes ved å utgjøre noe fagarbeideren trenger til å løse «arbeidsoppgavene».

Kunden ber for eksempel om å få utført «arbeidsoppgavene» med å få en garasje på tomten sin. For å gjøre «arbeidsoppgaven» har tømreren for eksempel behov for «kunnskap» om anatomien til treverket som skal brukes, og «ferdigheten2 for å spikre, samt «kontroll over de ytre betingelser» som har betydning., for eksempel ansvarsrett i kommunen for å oppføre garasjen. En respondent stilte det retoriske spørsmålet «Hva hjelper det om du eier alt på jorda og har alle ferdighetene til alle dyr og mennesker, dersom du ikke får byggetillatelse eller ansvarsrett? Da blir det ingen garasje».

Drøftingen av rammefaktorenes rolle i kompetansen og respondentenes svar, avdekket et behov for å klargjøre dimensjonen i kompetanse med betegnelse «kunnskapsområder» og underkategoriene «kunnskaper», «ferdigheter» og «kontroll over ytre betingelser». Kunnskapsområder ble endret til ressurser, for å unngå relativt like betegnelser på ulike nivåer i kategoriseringen. Relativt like betegnelser som «kunnskapsområder» og «kunnskaper», kunne lett forveksles i analyseprosessen, og det var vanskelig å bruke betegnelsen «kunnskapsområder» som hovedkategori til underkategorien «kontroll over ytre betingelser».

4 Bjelke, B. W. (2010). Læreplananalyse - Hvordan er kvalitetsutvikling som arbeidsprosess et kompetansekrav for å bli fagarbeider etter læreplanverket i Kunnskapsløftet. Kjeller: Høgskolen i Akershus. 
«Kontroll over ytre betingelser» er ifølge respondentene viktige «ressurser» å ha og kunne anvende. Respondentene anser «kontroll over ytre betingelser» som avgjørende for fremtidens fagarbeidere og dermed svært viktig å utvikle for elever, lærlinger og fagarbeidere. Det kan som nevnt være ansvarsretten til å oppføre garasjen og tilgang på spesielle materialer og verktøy. «Kontroll over ytre betingelser» handler ikke om «kunnskaper» og «ferdigheter», men om forhold utover det å vite hvordan og utføre fagarbeidet rent fysisk. Respondentene mener «kontroll over ytre betingelser» er sentralt og avgjørende for å vurdere en fagarbeiders kompetanseprofil, konkurranseevne og kompetansenivå (Bjelke, 2012; Nygren, 2004; Skårderud et al., 2005). I retningslinjer for læreplanarbeid kan man identifisere dimensjonen «ressurser» som ferdigheter og kunnskaper som skal kunne anvendes i konkrete situasjoner. «Kontroll over ytre betingelser» er ikke et tema der (Udir, 2005, 2011).

Studier viser at bransjemiljøer er opptatt av i hvilken grad yrkesutøveren har spesifikke «ressurser» for å løse «arbeidsoppgavene», og at slike «ressurser» til dels ikke kartlegges i fag-/svenneprøven. «Ressurser» er for eksempel «kunnskaper» og «ferdigheter» til å tegne (Deichman-Sørensen et al., 2011). Det er derfor usikkert i hvilken grad fag-/svenneprøven pr. i dag legger grunnlag for vurdering av kandidatens reelle evner til å løse «arbeidsoppgaver» i yrket.

\section{$\underline{\text { Kvalitetsutvikling som arbeidsprosess }}$}

«Kvalitetsutvikling som arbeidsprosess»er kompetansebegrepets tredje hoveddimensjon i denne studiens operasjonalisering av yrkeskompetansen, og innbefatter: «planlegging», «dokumentering av planlegging», «gjennomføring av planer», «dokumentering av gjennomføringen», «vurdering av gjennomføringen» og «dokumentering av vurderingen».

Flere av respondentene hadde vanskeligheter med å forstå dokumentasjonens rolle i «kvalitetsutvikling som arbeidsprosess», før den ble eksplisitt knyttet til hver av prosesselementene. En respondent uttalte: «Det blir lettere å forstå hva som skal dokumenteres, når kravet og behovet knyttes til alle faser i arbeidsprosessen. Mange tror at dokumentasjon er et mål uten mening, mens behovet for dokumentasjon er der med behovet for å vite og huske hva man skal gjøre, hva man har gjort og på hvilket grunnlag et produkt eller tjeneste kan utvikles eller er utviklet. Da må vi dokumentere hele prosessen». 
Ved bygging av garasjen som arbeidsoppgave, skal arbeidet planlegges med blant annet tegninger, kostnadsberegninger og tidsbruk. Garasjen skal bygges i henhold til planen, og kvaliteten på arbeidet skal vurderes og dokumenteres.

Slike arbeidsprosesser er kjente for respondentene og anerkjente allmenne krav til yrkesutøvelse (Dale \&Wærnes, 2003; Fonn, 2009; Havnen \& Buland, 2003; Sund, 2005; Udir, 2006; UiB, 2013), samtidig som forskning har vist at planlegging, vurdering og dokumentasjon står svakt ved gjennomføring av fag-/svenneprøver. Spesielt stod dokumentasjon svakt (Deichman-Sørensen et al., 2011).

Ved gjennomføring av arbeidsoppgaver foregår det underveisvurderinger og ofte revisjoner eller justering av de opprinnelige planene, slik at denne underkategorien til kvalitetsutvikling som arbeidsprosess har under-under-underkategorier som inneholder det samme kvalitetshjulet. Illustrasjonen nedenfor viser kvalitetshjulet med en reviderende prosess av planene under fasen med gjennomføring.

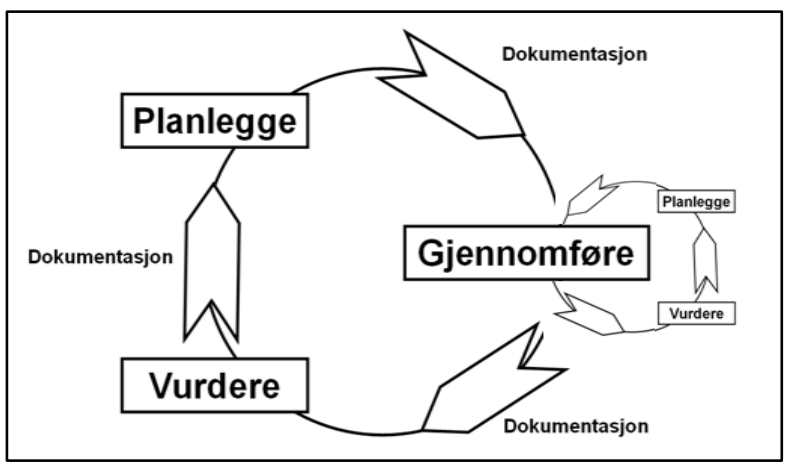

Figur 2 Kvalitetsutvikling som arbeidsprosess - Kvalitetshjulet

Hvilke behov det er for revisjon under gjennomføringen, er imidlertid ikke noe som alltid kan forutsees, men vil kunne inngå i beskrivelser av kompetansen til en fagarbeider i en samlet vurdering.

«Kvalitetsutvikling som arbeidsprosess» er en arbeidsform som kan bidra til kvalitetssikring og utvikling av tjenesten som ytes og yrkesutøverens kompetanse. Denne dimensjonen til kompetansen ansees å være et bærende felles element for alle yrkesområder. Samtidig er evnen til vurdering særdeles viktig for å sikre kvalitet og videre utvikling av faglig arbeid og yrkeskompetanse, og for å hindre stor oppdeling av i utgangspunktet helhetlige arbeidsoppgaver i ulike yrker (Wadel, 2007; Liljeström, 1979). 
Planlegging av nye arbeidsoppgaver baseres på erfaringer/dokumentert vurdering av gjennomførte arbeidsoppgaver. Etter endt gjennomføring vurderes den dokumenterte gjennomføringen. Både planlegging, gjennomføring og vurdering innbefatter dokumentasjon. Dokumentasjonen beskriver leveransen og danner grunnlag for videreutvikling.

I retningslinjer for vurdering av fag-/svenneprøver kan man identifisere dimensjonen «kvalitetsutvikling som «arbeidsprosess» med krav til innhold i fag-/svenneprøven. Vi finner også denne dimensjonen sporadisk implementert i læreplaner for fag (Forskrift til opplæringslova, 2006; Hårstad, 2009; KUF, 1997; Large, 2001; Nasjonalt læremiddelsenter, 1998; Sund, 2005; Udir, 2005, 2010, 2011, 2017).

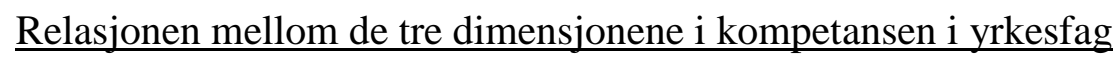

Deichman-Sørensen et al. (2011) påviste svakheter ved fag-/svenneprøven som kan indikere at aktørene i yrkesopplæringen ikke har et avklart forhold til relasjonen mellom de ulike dimensjonene i kompetansekravet. Utdanningsmyndighetene har heller ikke presentert en klar forståelse av relasjonen mellom de ulike begrepene i deres operasjonalisering av yrkeskompetansen.

Analysen har som mål å vise relasjoner mellom dimensjonene og underkategoriene i det operasjonaliserte kompetansebegrepet som studien har kommet fram til. De tre dimensjonene med tilhørende underkategorier som brukes i analysen av læreplaner, er det gitt oversikt over til sist i kapittelet om metode.

Disse funnene fra intervjuene ble strukturert og satt inn i et skjema, som respondentene brukte som verktøy i sine læreplananalyser. Se figur 3, 4, 5 og 6.

\section{Funn fra analyse av læreplanene for opplæring i bedrift}

Med utgangspunkt i funn fra intervjuene og de felles kategoriene som analyseskjemaet er bygd opp rundt, se figur 3, gjennomførte respondentene i dialog med forskeren og hverandre en tretrinns analyseprosess av sine respektive læreplaner for bedrift/Vg3.

1. Kode kompetansemålene i læreplanen som tilhører de ulike dimensjonene og underkategoriene i kompetansen

2. Sett de identifiserte kompetanseelementene inn i matrisen og marker relasjonene

3. Beskriv kompetansen som prosatekst 
$\underline{\text { Trinn 1. Koding av kompetansemålene i læreplanen som tilhører de ulike dimensjonene og }}$ underkategoriene i kompetansen

Læreplanens kompetansemål ble dekomponert og markert med forskjellige fargekoder.

Arbeidsoppgaver ble markert med gul, ressurser med grønn og Kvalitetsutvikling som arbeidsprosess med turkis. Se eksempel i figur 4.

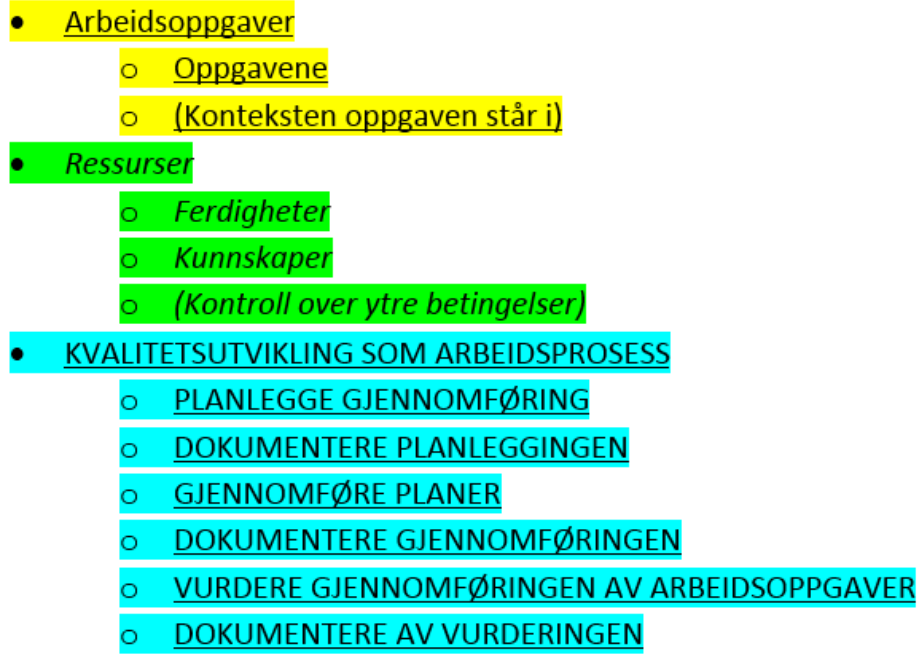

Figur 3 Markeringskode

Kompetansemålene må forstås og tolkes ut fra det reelle kompetansebehovet i yrket slik det er beskrevet i formålet med faget, beskrivelse av hovedområdene og hvordan grunnleggende ferdigheter er integrert i kompetansemålene (Udir, 2009). Respondentene opplevde noen utfordringer i kodingen av kompetansemålene, knyttet til tolkning av innholdet i teksten:

- Kompetansemålene er ikke alltid formulert med et konsistent begrepsapparat

- Kompetansemålene utfyller ikke hverandre til en helhetlig beskrivelse av yrkeskompetansen

- Kompetansemålene refererer seg ikke til hverandre

- Det er uklart hvordan de ulike dimensjonene og underkategoriene i kompetansen forholder seg til hverandre

- Flere forskjellige ord kan muligens uttrykke det sammen innholdet

- Det kan stilles spørsmål ved om samme bokstavering har ulikt innhold

- Det er uklart om eksplisitt nevnte kompetanseelementer, ekskluderer eller inkluderer andre elementer 
- Noen kompetansemål er svært generelle og gir rom for å velge svært ulik konkretisering.

- Andre kompetansemål er svært konkrete og ekskluderende for alternative innholdsmomenter som kan oppleves relevante

- Kompetansemålene gjentar i noen grad kompetanseelementer og relasjon mellom elementene, uten at det er forståelig hva gjentakelsen skal tjene

Spørsmål som ble reist i forbindelse med tolking og koding, ble skrevet inn som kommentarer til kompetansemålene. I figur 4 er det vist eksempler på tolkninger og spørsmål knyttet til kompetansemål i læreplanen for tømrerfag:

\begin{tabular}{|c|c|}
\hline Kompetansemål som er kodet med farger & Spørsmål til tolkningen \\
\hline Mål for opplæringen er at lærlingen skal kunne & Innledende tekst \\
\hline $\begin{array}{l}\text { - UTF } \varnothing \text { RE byggie- og monteringsarbeid } \\
\text { etter teikningar og beskrivingar }\end{array}$ & $\begin{array}{l}\text { Avgrenser dette kompetansemålet } \\
\text { arbeidet til bare å utføre? Ikke } \\
\text { planlegge, dokumentere og vurdere? } \\
\text { Er det bare bygge- og monteringsarbeid } \\
\text { som skal utføres etter tegninger og } \\
\text { beskrivelser? }\end{array}$ \\
\hline $\begin{array}{l}\text { - } \quad \text { byggie nye utvendige og innvendige } \\
\text { konstruksjonar av tre og stål }\end{array}$ & $\begin{array}{l}\text { Skal byggingen planlegges, utføres, } \\
\text { vurderes og dokumenteres? } \\
\text { Kan det bygges gamle konstruksjoner? } \\
\text { Skal det bare bygges av tre og stål? }\end{array}$ \\
\hline $\begin{array}{l}\text { - DOKUMENTERE eige arbeid ved bruk } \\
\text { av preaksepterte løysingar }\end{array}$ & $\begin{array}{l}\text { Skal dokumentasjon av eget arbeid bare } \\
\text { skje ved bruk av preaksepterte } \\
\text { løsningen? }\end{array}$ \\
\hline $\begin{array}{l}\text { PLANLEGGJE, UTFøRE, DOKUMENTERE } \\
\text { OG VURDERE eiqe arbeid }\end{array}$ & $\begin{array}{l}\text { Er det krav til at alt arbeid skal } \\
\text { planlegges, gjennomføres, vurderes og } \\
\text { dokumenteres? } \\
\text { Hvilke kunnskaper og ferdigheter stilles } \\
\text { det krav om å anvende? }\end{array}$ \\
\hline
\end{tabular}

Figur 4 Eksempel på uklare kompetansemål og tolkning av disse

$\underline{\text { Trinn 2. Plassering av de identifiserte kompetanseelementene i matrisen og markering av }}$ relasjonene 
I denne delen av prosessen ble hvert identifisert og kategorisert kompetanseelement fra hvert kompetansemål satt inn i en matrise hvor relasjonen mellom dem ble markert. Se figur 5.

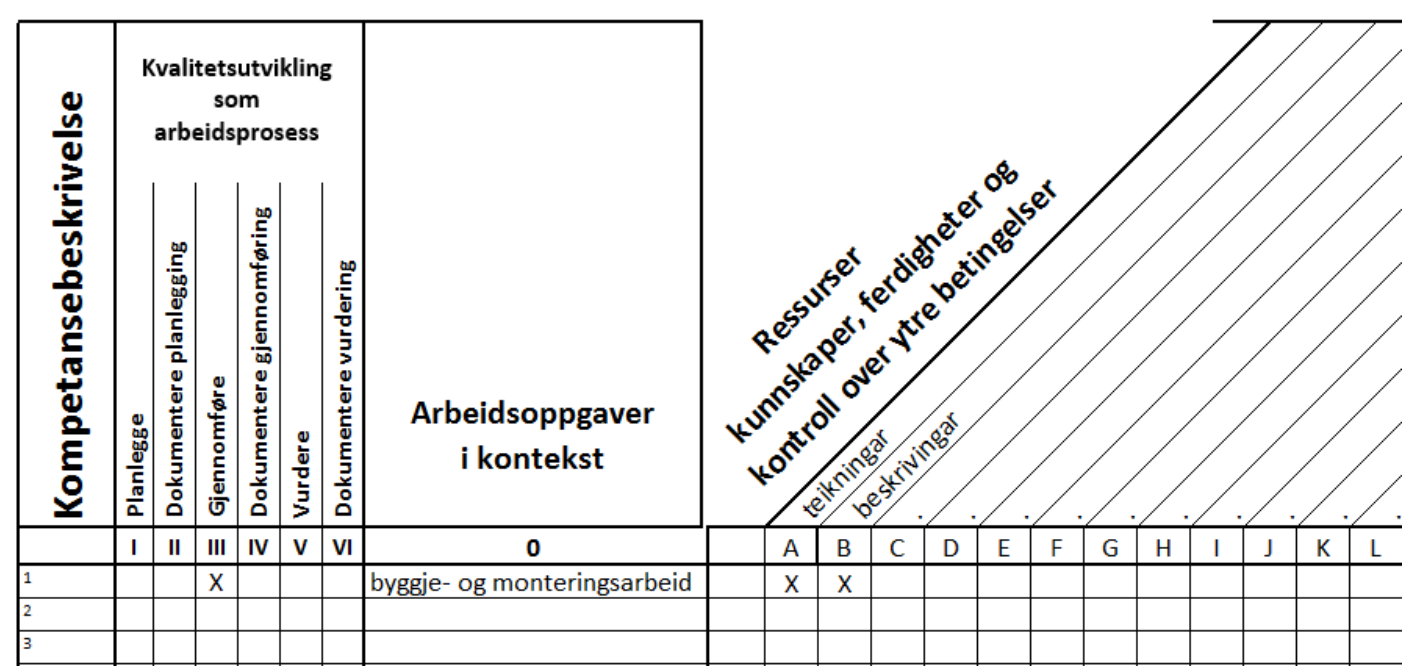

Figur 5 Skjema for analyse av læreplaner

I den første kolonnen helt til venstre benevnt med kompetansebeskrivelse, ble det angitt hvilket kompetansemål som tolkes. Det finnes unike koder for disse sentralt, men i denne studien ble de nummerert fortløpende i den rekkefølge de ble tolket. I figur 5 eksemplifisert med «1» fra oversikten over kompetansemål i figur 4.

I den tredje hovedkolonnen i skjemaet ble dernest «arbeidsoppgaver i kontekst» beskrevet, slik de står i læreplanen for fag. I figur 5 eksemplifisert med «byggje- og monteringsarbeid» fra oversikten over kompetansemål i figur 4.

I den andre hovedkolonnen for «kvalitetsutvikling som arbeidsprosess» ble fasene i arbeidet registrert. For kompetanseelementer tilhørende «kvalitetsutvikling som arbeidsprosess», var skjemaet pre-utfylt fordi disse underkategoriene var like i de ulike lærefagene/yrkene. Derved kan man ved hjelp av avkryssing skrive inn tolkningen. I figur 5 er det gitt eksempel på at læreplanmålet som har i seg arbeidsoppgaven om «byggje- og monteringsarbeid», fra oversikten over kompetansemål i figur 4, i første omgang er tolket å omfatte underkategoriene «gjennomføre» $\mathrm{i}$ «kvalitetsutvikling som arbeidsprosess».

I den fjerde hovedkolonnen ble de «ressurser» som skal kunne anvendes til å løse arbeidsoppgavene skrevet inn, som «kunnskaper», «ferdigheter» og «kontroll over ytre betingelser». Deretter ble det avsatt kryss for om disse ressursene skal anvendes i spesifikke 
arbeidsoppgaver og faser av arbeidet. I figur 5 er det gitt eksempel, fra oversikten over kompetansemål i figur 4, på tolkning av at «teikningar» og «beskrivningar» skal kunne anvendes ved «byggje- og monteringsarbeid» ved «gjennomføring», under hovedkategorien «kvalitetsutvikling som arbeidsprosess».

I følge respondentene kan hele kompetanseområdet i læreplanen for et lærefag beskrives slik. Respondentene mente imidlertid dette var en noe fremmed måte å beskrive kompetansen på. Derfor var det behov for å bruke et mer vanlig layout for å presentere resultatene av læreplananalysen.

Trinn 3. Beskrivelse av kompetansen med prosatekst

Matrisen med resultatet av analysen ble til slutt skrevet ut i prosatekst. Resultatet ble en mer kortfattet og konsistent beskrivelse av kompetansen/målet for opplæringen enn det læreplanen i dagens form gir, men med samme sjanger. I figur 6 er det vist eksempel fra analyse av læreplanen i tømrerfaget. Dimensjonene i yrkeskompetansen er her skrevet inn i en kolonne til høyre for å vise sammenhengen mellom analysekategoriene og prosateksten. 


\begin{tabular}{|c|c|}
\hline Prosatekst på kompetansen etter analysen & Dimensjoner i kompetansen \\
\hline $\begin{array}{l}\text { Målet for opplæringen er at lærlingen skal kunne, } \\
\text { planlegge, dokumentere planlegging, gjennomføre, } \\
\text { dokumentere gjennomføring, vurdere og dokumentere } \\
\text { vurdering av } \\
\text { bygging, vedlikehold, oppgradering og rehabilitering av } \\
\text { innredninger, utvendige trekonstruksjoner, og } \\
\text { bygninger bestående av ulike innvendige og utvendige } \\
\text { gulv/etasjeskiller, vegger og tak } \\
\text { med bruk av kunnskaper og ferdigheter innenfor } \\
\text { - HMS, } \\
\text { - gjeldende regelverk, } \\
\text { - preaksepterte løsninger, } \\
\text { - avfallshandtering, } \\
\text { - beskrivelser, } \\
\text { - tegninger, } \\
\text { - tre, } \\
\text { - stål, } \\
\text { - mur, } \\
\text { - betong, } \\
\text { - vinduer, } \\
\text { - dører, } \\
\text { - bygge-tradisjoner, } \\
\text { - stillas, } \\
\text { - måleverktøy, } \\
\text { - estetikk, } \\
\text { - kulturelle verdier, } \\
\text { - ergonomiske prinsipper, } \\
\text { - etikk, } \\
\text { - moralske retningslinjer, } \\
\text { - geometri, } \\
\text { - digitale verktøy, } \\
\text { - skisser, } \\
\text { - konstruksjonstegninger, } \\
\text { - bygningsfysikk, } \\
\text { - muntlig kommunikasjon, } \\
\text { - lesing, } \\
\text { - skriving, } \\
\text { - IKT og } \\
\text { - regning av vekt, areal, volum og mengder. } \\
\text { - }\end{array}$ & $\begin{array}{l}\text { (Innledende formulering) } \\
\text { Kvalitetsutvikling som } \\
\text { arbeidsprosess } \\
\text { Arbeidsoppgaver }\end{array}$ \\
\hline
\end{tabular}

Figur 6 Prosatekst på kompetansen etter analysen 
Denne presentasjonen av innholdet i læreplanen reduserte antall ord i forhold til læreplanen fra 750 til ca 100.

\section{Oppsummering og drøfting av funn fra læreplananalysen}

Spørsmålene som kom opp i forbindelse med tolkning og koding av teksten, viste at det var rom for svært ulik tolkning av innholdet i læreplanene. Det kan også være en utfordring å oppnå at elever, lærlinger, lærere, instruktør, sensorer, prøvenemnder og klagenemnder med flere har en felles forståelse av hva som er målet for utdanningen og hva som skal vurderes underveis og til fag-/svenneprøven.

Det store rommet for ulike tolkninger kan forårsake at læreplanene ikke sikrer en nasjonal standard for fag-/svenneprøver og fagarbeiderkompetanse.

\section{Arbeidsoppgaver}

Det viste seg at arbeidsoppgaver var gjenkjennelige komponenter i kompetansebeskrivelsen i læreplanene på et overordnet nivå.

Konteksten som en arbeidsoppgave står i, som respondentene mente var avgjørende for en yrkesutøvers forutsetninger til å løse de daglige utfordringene, var imidlertid ikke tydelige i læreplanene. Det viste seg at læreplanene ikke har en kompetansebeskrivelse som omfatter konteksten og yrkeskompetansen på en måte som samsvarer med kravene som stilles i arbeidslivet. Dette kan bidra til å svekke muligheten til å etablere valide fag-/svenneprøver og andre vurderingssituasjoner i yrkesfag. Dersom fag-/svenneprøvene skal være valide i henhold til arbeidslivets kompetansekrav, vil de, uten at denne del av kompetansen beskrives eksplisitt i læreplanene, bestå av en avgjørende ukjent faktor. Dersom fag-/svenneprøven innbefatter dette kompetanselementet, vil den være i tråd med arbeidslivets kompetansekrav, men ikke i tråd med læreplanverket. Den vil være forskriftsstridig på grunn av manglende samsvar mellom fag-/svenneprøvens og læreplanens innhold.

Fraværet av beskrivelse av hvilken kontekst arbeidsoppgaven står i, er ifølge funn fra intervjuene i denne studien, en betydelig mangel i læreplanverket. Dersom fagarbeidere skal utvikle forståelse for hvilke ressurser som kreves for å løse arbeidsoppgaven og å håndtere utfordringer knyttet til disse, bør læreplanene innbefatte en beskrivelse av hvilken kontekst lærlingen skal kunne mestre arbeidsoppgavene i (Michelsen \& Olsen, 2007). Dette var delvis 
beskrevet i enkelte tidligere læreplaner, men ble tatt ut av læreplanene i Reform 94 (Kirke- og undervisningsdepartementet (KUD), 1976; KUF, 1993; Udir, 2017).

\section{$\underline{\text { Ressurser }}$}

Utprøving av analyseverktøyet viste at hvilken kontekst arbeidsoppgavene skulle kunne utføres i, er fraværende i læreplanverket. Hvilke behov elever har for kontroll over ytre betingelser er også uklart (Udir, 2005; 2011). Ludvigsen-utvalget beskriver heller ikke kontroll over ytre betingelser som en del av den sentrale kompetansen for framtiden (NOU, 2015:8). Går vi imidlertid tilbake til eldre læreplaner, finner vi slike rammefaktorer omtalt (KUD, 1976). Der skulle elever og lærlinger orientere seg om hvilken kontroll over ytre betingelser som var nyttig å ha, og hvilken kontekst kompetansen skulle prøves i, i tråd med respondentenes beskrivelse av sine yrkers arbeidsoppgaver og kompetansebehov.

\section{$\underline{\text { Kvalitetsutvikling som arbeidsprosess }}$}

Denne studien med utprøving av analyseverktøyet avdekket at det var hensiktsmessig å identifisere arbeidsoppgaver som konstituerer yrket først, dernest hvilke ressurser som skulle anvendes for å løse arbeidsoppgavene, for sist å avklare hvordan kvalitetsutvikling som arbeidsprosess er et krav knyttet til å løse arbeidsoppgaven og anvende ressursene. Gjennom en slik rekkefølge oppleves kvalitetsutvikling som arbeidsprosess som mer relevant og som en egen dimensjon i kompetansen. Respondenten forstod bedre hva kvalitetsutvikling som arbeidsprosess var etter at arbeidsoppgavene og ressursene var identifisert.

Utprøving av analyseverktøyet avdekket flere underkategorier til de ulike dimensjonene i kompetansen. Dette krevde en bedre forklaring på hvilke relasjoner alle kompetanseelementene har til hverandre og hvordan dette kunne dokumenteres og formidles på en bedre måte enn tidligeres (Asplan Analyse, 1992; Bjelke, 2012; Nilsen \& Sund, 2008).

Kanskje kan denne metodikken som synliggjør både kompetansens dimensjoner og relasjonen mellom dem avhjelpe de problemene ved gjennomføring av fag-/svenneprøver som Deichman-Sørensen et al. (2011) påviste?

5 Bjelke, B. W. (2010). Læreplananalyse - Hvordan er kvalitetsutvikling som arbeidsprosess et kompetansekrav for å bli fagarbeider etter læreplanverket i Kunnskapsløftet. Kjeller: Høgskolen i Akershus. 


\section{Oppsummering og drøfting av studiens resultater}

Basert på data i denne studien er det vist hva yrkeskompetanse kan være og at dagens læreplaner mangler to viktig underkategorier i dimensjon til yrkeskompetansen. Studien har også resultert i utvikling av et analyseverktøy som kan brukes til å identifisere kompetanseelementer i læreplanene som er relevante å prøve til fag-/svenneprøven. Funnene kan kort oppsummeres i følgende punkter:

- Yrkeskompetanse kan operasjonaliseres som evne til å planlegge, gjennomføre og vurdere løsning av arbeidsoppgaver i ulike kontekster ved anvendelse av ressurser, og å kunne dokumentere denne prosessen.

- I analyse av yrkeskompetanse er det hensiktsmessig å identifisere arbeidsoppgaver som konstituerer yrket først, dernest hvilke ressurser som skal anvendes for å løse arbeidsoppgavene, for sist å avklare i hvilken grad kvalitetsutvikling som arbeidsprosess er et krav knyttet til å løse arbeidsoppgaven og anvende ressursene.

- Det er ikke samsvar mellom innholdet i læreplanene og yrkenes reelle kompetansekrav. Læreplanverket mangler beskrivelse av konteksten som arbeidsoppgavene står i og yrkesutøverens behov for kontroll over ytre betingelser som en ressurs

- Læreplanenes kompetansebeskrivelser er uklare og gir stort rom for ulik tolkning av målet for opplæringen

- Et funksjonelt skjema som bygger på prinsipper for relasjon mellom de ulike dimensjonene og underkategoriene i kompetansen, kan brukes for å analysere kompetanse og læreplaner.

- Dersom fag-/svenneprøven skal være basert på innholdet i læreplanene, kan vurderingen være legal og rasjonell, men ikke nødvendigvis legitim, sett i lys av fagarbeideres reelle behov for kompetanse. Reelle kompetansebehov må eventuelt tolkes inn i læreplanens beskrivelser for at fag-/svenneprøven også skal være legitim.

\section{Kvaliteten på databehandlingen i studien (validitet)}

En av utfordringene i arbeidet med utvikling av vurdering i yrkesopplæringen, er målet om å gjøre vurderingen både legitim, legal og rasjonell. Studien bygger på streben etter en rasjonell 
kritikk, men med et forsøkt på å presentere den legitime og legale. Utfordringen ligger antakelig i om studiens konklusjoner er legitime. Bare framtiden vil vise om løsningene er legitime i den forstand at de er aksepterte i sin alminnelighet blant fremtidens aktører i yrkesopplæringen.

Hvorvidt den løsningen for analyse av kompetanse som studien viser bidrar til å oppfylle legale idealer, kan blant annet vurderes opp mot om analyseverktøyet bidrar til å nå forvaltningslovens krav til forutsigbarhet og likebehandling ved fastsetting av karakter i fag/svenneprøven/eksamen som enkeltvedtak (Forvaltningsloven, 1967). Studien har med andre ord som formål å bidra til økt validitet og reliabilitet ved vurdering i yrkesfag.

Hvorvidt databehandlingen i utvikling av analyseverktøyet er valid og reliabelt, er et annet spørsmål. Opplevelsen av validiteten, avhenger antakelig av om aktørene vil operasjonalisere kompetanse slik det gjøres i denne studien. Dersom ulike aktører ikke benytter den samme operasjonalisering av kompetanse og kompetansebeskrivelsen i læreplanene, vil antakelig ikke analyseverktøyet oppleves relevant, og det er følgelig svært vanskelig å oppnå noen særlig grad av reliabilitet. Studien viste behov for revisjon av begreper og analyseprosesser for å etablere en felles forståelse av relevans og bidrag til validitet. Da felles forståelse var etablert, gikk det raskere for de ulike respondentene å analysere den samme læreplanen med $ø k t$ grad av reliabilitet.

Dersom analyseverktøyet som er utviklet ikke oppleves som den beste løsningen, vil verktøyet likevel kunne føre til en større grad av refleksjon i læreplananalysen, og på den måten være valid i forhold til formålet om å bidra til økt validitet i fag-/svenneprøver.

Det kreves et visst engasjement hos brukerne for å gå så grundig til verks i læreplananalyse som analyseverktøyet legger opp til. Slik sett kan det være en viss fare for at inngangsterskelen til å bruke analyseverktøyet er for høy. En høy terskel for noen til å ta analyseverktøyet i bruk, svekker imidlertid ikke verdien av analyseverktøyet for alle. Dernest er det grunn til å stille spørsmål ved hva man skal med en så grundig analysemodell til bruk i bare en fase av læreplanimplementeringen. Høy kvalitet i ett ledd, hindrer imidlertid at dette leddet i valideringskjeden svikter (Sandvik \& Buland 2014). Spørsmålet ved hva en så stor satsing i et av valideringskjedens ledd skal kunne bidra med totalt, leder til at det er behov for oppfølgende forskning og utprøving av analyseverktøyet. 


\section{Overføringsverdi - Oppfølgende studier}

Som nevnt i avsnittet med oppsummering og drøfting av studiens resultater, foreslås det her noen oppfølgende studier. I det følgende presenteres noen antakelser om hva analyseverktøyet kan benyttes til, men som altså krever nærmere undersøkelser før man kan trekke slutninger.

\section{Sammenligning av ulike kompetansebeskrivelser}

Analyseverktøyet kan brukes til kartlegging av lærlingens kompetanse, og til sammenligning med målene for opplæringen. Det kan også brukes til å kartlegge voksenes realkompetanse. Analyseverktøyet kan brukes til å sammenligne kompetansebeskrivelser i de ulike fasene ved utvikling av læreplaner. Med inspirasjon fra Goodlad (1979) beskriver Engelsen (2003) ulike faser. Denne studien tok for seg analyse av kompetansebehov i ulike yrker og den formelle læreplanen for de respektive yrkene. Antakelig kan det samme analyseverktøyet brukes til å analysere ideenes læreplan, den oppfattede læreplanen i undervisningssituasjonen og den erfarte læreplan. Analyseverktøyet kan antakelig benyttes til å sammenligne disse utviklingstrinnene.

Analyseverktøyet kan også brukes til å sammenligne yrkeskompetansen i læreplanene med andre relevante kompetansebeskrivelser som samarbeider om utvikling av internasjonale standarder for yrker og vurderingssystemer. Til eksempel kan nevnes European credit transfer system for vocational education and training (ECVET), The European Qualifications Framework for Lifelong Learning (EQF), Europass, Nasjonalt kvalifikasjonsrammeverk for livslang læring (NKR). (Council of Europe, 2015; 2017; KD, 2011; Kompetanse Norge, 2017; Senter for internasjonalisering av utdanning, 2015).

Analyseverktøyet utgjør et system som kan brukes i mange forskjellige kompetansebeskrivelser og gjøre sammenligning av kompetansebeskrivelser transparent. Dersom vi bruker analyseverktøyet til å analysere ulike dokumenttyper, kan det ligne litt på Goodlad sin modell for analyse av læreplaner, men avgrenser seg til kun til å sammenligne mål for kompetanse, mens Goodlad tar for seg flere didaktiske komponenter (Goodlad, 1979).

\section{Kjennetegn på vurderbare kompetansemål}

Bakgrunnen for å utvikle og formidle analyseverktøyet, var at mange læreplaner i yrkesfag oppleves uklare på hva som er målet for opplæringen og at uklarheter sannsynligvis fører til lite relevant vurdering av elever og lærlingers yrkeskompetanse (Bjelke, 1996; Udir, 2008; 
Deichman-Sørensen et al.,2011). Videre finner mange lærebedrifter liten nytte i å bruke læreplanverket slik det er utformet i dag. (Riksrevisjonen, 2013). Analyseverktøyet kan kanskje anvendes som grunnlag for en forenkling og klargjøring av innholdet i læreplanene på en måte som fagfolk kjenner seg igjen i, og dermed føre til at de kanskje i større grad blir brukt i opplæringen.

I figur 7 er det oppstilt påstander som viser et eksempel på hvordan begrepene fra analyseverktøyet kan brukes som kjennetegn på hva som er vurderbare kompetansemål i utviklingen av læreplaner. Begreper i kjennetegnene er hentet fra Utdanningsdirektoratets retningslinjer for utarbeidelse av læreplaner (Udir, 2005) og forskrifter om fag-/svenneprøver. Denne studiens navn på disse kompetansedimensjonene, står oppført i parentes (Udir, 2005; 2011).

1. Kompetansemålene viser hvilke oppgaver og komplekse utfordringer (oppgaver) eleven skal løse i ulike situasjoner (kontekster).

2. Kompetansemålene viser hvilke ferdigheter og kunnskaper (ressurser som eventuelt inkluderer kontroll over ytre betingelser) som skal kunne anvendes i konkrete situasjoner (oppgaver i kontekst/ arbeidsoppgaver).

3. Kompetansemålene viser hva som er kunnskaper og ferdigheter (ressurser) på den ene side, og hva som er oppgaver og komplekse utfordringer (arbeidsoppgaver) på den annen side.

4. Kompetansemålene viser hvilke oppgaver og komplekse utfordringer i konkrete situasjoner (oppgaver i kontekst - arbeidsoppgaver), og hvilke kunnskaper og ferdigheter(ressurser som eventuelt inkluderer kontroll over ytre betingelser), som skal inngå i fag-/svenneprøvens krav om å inneholde planlegging, gjennomføring, vurdering og dokumentasjon (kvalitetsutvikling som arbeidsprosess).

Figur 7 Kjennetegn på vurderbare kompetansemål

\section{Avsluttende ord}

Problemstillingen til den studien som er rapportert i denne artikkelen var "Hvordan kan vi identifisere kompetanseelementer i læreplanene som er relevante å prøve til fag/svenneprøven?” På bakgrunn av at vurdering er en studie hvor begrepsavklaringer om kompetansebeskrivelser står sentralt, er kompetanse i yrkesfag operasjonalisert, basert på drøfting av teori, intervjuer med fagarbeidere og analyse av læreplaner. Videre er det vist hvordan de ulike dimensjonene i kompetansen har relasjon til hverandre og hvordan disse 
kompetanseelementene kan gjenfinnes i læreplanene ved hjelp av et analyseverktøy. Dette kan være en hjelp til å gjøre fag-/svenneprøvene mer valide. Studien har vist at læreplanenes kompetansebeskrivelse ikke gjenspeiler sentrale dimensjoner i yrkeskompetanse, som for eksempel konteksten oppgavene står i og kontroll over ytre betingelser. Studien har også pekt på et behov for nye studier med utprøving av analyseverktøyet for sammenligning av kompetansebeskrivelser og utforming av vurderbare kompetansemål i læreplanene.

Førsteamanuensis Sigrun Saur Stiklestad, Professor Grete Haaland og andre ved Høgskolen i Oslo og Akershus har gitt veiledning, bidrag og tilbakemeldinger. I tillegg har flere yrkesutøvere som forblir anonyme bidratt med undersøkelser og tilbakemeldinger. Takk til dem alle.

\section{Litteratur}

Asplan Analyse (1992). Kompetanse og utdanningsbehov i barnevernet. Sandvika: Asplan Analyse.

Bjelke, B. W. (1996). For dårlige høringsinstanser har gitt R94-problemer. Skolefokus, 17, 42.

Bjelke, B. W. (2012). Vurdering - Hva kan kjennetegne ulike kompetansenivåer hos yrkesutøvere. Kjeller: Høgskolen i Oslo og Akershus. https://oda.hio.no/jspui/bitstream/10642/1217/2/mayp_bjelke_2012.pdf

Bjørndal, B. \& Lieberg, S. (1979). Nye veier i didaktikken. Oslo: Aschehoug.

Council of Europe (2015). Kommisjonen for de Europeiske felleskap - EU (2015). The European Credit system for Vocational Education and Training (ECVET). Lest 12.08.2015 http://ec.europa.eu/education/policy/vocational-policy/ecvet_en.htm

Council of Europe (2017). Kommisjonen for de Europeiske felleskap - EU (2011). The European Qualifications Framework for Lifelong Learning. Lest 26.03.2017 https://ec.europa.eu/ploteus/sites/eac-eqf/files/leaflet_en.pdf

Dale, E. L. \& Wærness, J. I. (2003). Differensiering og tilpasning i grunnopplceringen. Oslo: J. W. Cappelens Forlag.

Deichman-Sørensen, T., Høst, H., Michelsen, S., Nore, H., Olsen, O. J., \& Tønder, A. H. (2011). Prøvenemndenes arbeid med fag-og svenneprøver - En undersøkelse av fem fag. Oslo: FAFO

Engelsen, B. U. (2003). Ideer som formet vår skole. Oslo: Gyldendal Norsk forlag AS.

Fonn, K. H., (2009). Integrasjon eller autonomi i fag- og yrkesopplæringen. En kombinert iverksettingsstudie av "Vandreboka". Trondheim: NTNU.

Forskrift til opplæringslova (2006). Forskrift til opplæringslova. FOR-2006-06-23-724. Kunnskapsdepartementet. Lest 22.10.2011, http://www.lovdata.no/for/sf/kd/kd20060623-0724.html 
Forvaltningsloven (1967). Lov om behandlingsmåten i forvaltningssaker. LOV-2014-05-0916. Justis- og beredskapsdepartementet. Lest 16.09.2015, https://lovdata.no/dokument/NL/lov/1967-02-10

Goodlad, J. I. (1979). Curriculum inquiry. The study of curriculum practice. New York: McGraw-Hill.

Grønmo, S. (2016). Samfunnsvitenskapelige metoder (2. utgave). Bergen: Fagbokforlaget.

Halvorsen, K. (2008). Å forske på samfunnet. Oslo: J. W. Cappelen Forlag as.

Havnen, V. \& Buland, T. (2003). Underveis? - Sluttrapport fra evaluering av prosjektet ”Alternative vurderings- og prøveformer i fagopplæringen”. Trondheim: SINTEF.

Hiim, H., \& Hippe, E. (1989). Undervisningsplanlegging for yrkeslerere. Oslo: Universitetsforlaget.

Kirke- og undervisningsdepartementet - KUD (1976). Læreplan for den videregående skole, Studieretning for håndverks- og industrifag, Grunnkurs snikkarlinje. Oslo: Gyldendal Norsk Forlag A/S.

Kirke, utdannings- og forskningsdepartementet - KUF (1993). Læreplan for videregående opplaring, Studieretning for trearbeidsfag, Studieretningsfagene i grunnkurs trearbeidsfag. Oslo: Kirke-, utdannings- og forskningsdepartementet.

Kirke, utdannings- og forskningsdepartementet - KUF (1997). Retningslinjer for fagprøve for tømrerfaget. Oslo: Kirke-, utdannings- og forskningsdepartementet.

Kompetanse Norge (2017). Realkompetanse. Lest 26.03.2017, https://www.kompetansenorge.no/realkompetanse/

Kunnskapsdepartementet (2011). Nasjonalt kvalifikasjonsrammeverk for livslang læring NKR. Oslo: Kunnskapsdepartementet

Kvale, S., Brinkmann, S., Anderssen, T. M., \& Rygge, J. (2015). Det kvalitative forskningsintervju (3. utg., 2. oppl. ed.). Oslo: Gyldendal akademisk.

Large, I. (2001). Helhetlig kompetanse - fra idé til gjenstand for vurdering i fag-og svenneprøver. Oslo: Det utdanningsvitenskapelige fakultet - Pedagogisk forskningsinstitutt.

Liljeström, R. (1979). Kultur och arbete. Stockholm: Liber Förlag.

Lynggaard, K. (2010). Dokumentanalyse. I S. Brinkmann \& L. Tanggaard (Red.), Kvalitative metoder - En grundbog (s.137-151). København: Hans Reitzels Forlag.

Michelsen, S. \& Olsen, O. J. (2007). VET-LSA (International Comparativ Large Scale Assessment in Vocational Education and Training) - En forstudie. Bergen: Universitetet i Bergen.

Monsen, L. (2004). Kriterier for valg av lærestoff. Bedre skole 2004 (2), 36-46. Oslo: Utdanningsforbundet. 
Nasjonalt læremiddelsenter (1998). Veiledning for prøvenemndsmedlemmer. Oslo: Nasjonalt læremiddelsenter.

Nilsen, S. E. \& Sund, G. H. (2008). Lœring gjennom praksis. Oslo: PEDLEX Norsk skoleinformasjon.

Nore, H. (2008). TIP: Bred bakgrunn for mange yrker - en utfordring både i læreplanarbeidet og skolehverdagen. Yrke. Tidsskrift om yrkesopplæring. 2008, 52(3), 30-32. Lest 26.03.2017, https://www.utdanningsforbundet.no/upload/Tidsskrifter/Yrke/Yrke\%20nr.3\%20200 $\underline{\text { 8.pdf }}$

NOU 2015:8 (2015). Fremtidens skole - Fornyelse av fag og kompetanser. Oslo: Kunnskapsdepartementet.

Nygren, P. (2004). Handlingskompetanse - Om den profesjonelle person. Oslo: Gyldendal Norsk Forlag AS.

Riksrevisjonen (2013). Riksrevisjonens undersøkelse av fagopplæring i bedrift - Dokument 3:6 (2012-2013). Oslo: Fagbokforlaget

Ryen, A. (2002). Det kvalitative intervju. Bergen: Fagbokforlaget Vigmostad \& Bjerke AS.

Sandvik, L. V. \& Buland T. (red.) (2014) Vurdering i skolen. Utvikling av kompetanse og fellesskap. Sluttrapport fra prosjektet Forskning på individuell vurdering i skolen (FIVIS). Trondheim: NTNU, program for lærerutdanning, og SINTEF.

Sannerud, R. (2006). Yrkeskompetanse - En begrepsanalyse. I: E. Askerøi og O. Eikeland (red), Som gjort, så sagt, Yrkeskunnskap og yrkeskompetanse (s. 219-239). Kjeller: Høgskolen i Akershus.

Senter for internasjonalisering av utdanning - (2015). Europass. Lest 12.08.2015, http://siu.no/Europass

Skjervheim, H. (1996). Deltakar og tilskodar og andre essays. Oslo: H Aschehoug \& Co. (W. Nygaard).

Skårderud, F., Fauske, H., Nygren P., Nilsen, S. \& Kollestad, M. (2005). Profesjonelle handlingskompetanser - utakter mellom utdanning og yrkespraksis. Norsk pedagogisk tidsskrift. 89 (6). (s. 461-476)

St.meld. nr. 30 (2003-2004) (2004). Kultur for læering. Oslo: Utdannings- og forskningsdepartementet.

Sund, G. H. (2005). Forskjellighet og mangfold - mulighet eller begrensninger for individ og arbeidsplass. Roskilde: Roskilde Universitetscenter - Forskerskolen Livslang læring.

Thagaard, T. (2002). Systematikk og innlevelse - En innføring i kvalitativ metode (2.utgave). Bergen: Fagbokforlaget Vigmostad \& Bjørke AS

Universitetet i Bergen (2013). Handbok for kvalitetssikring av universitetsstudia (4.utg.). Bergen: Bodoni Hus Bergen.

Utdanningsdirektoratet (2005). Retningslinjer for arbeid med læereplaner for fag. Oslo: Utdanningsdirektoratet. 
Utdanningsdirektoratet (2006). Nasjonale føringer for kvalitet i fag-og yrkesopplaringen. Oslo: Utdanningsdirektoratet.

Utdanningsdirektoratet (2008). Fag- og svenneprøven- Ny, særskilt prøving av kunnskap eller videreutvikling av dagens prøve? Oslo: Utdanningsdirektoratet

Utdanningsdirektoratet (2010). Rundskriv om forskriftsendring - Individuell vurdering, Sak 2010/1156

Utdanningsdirektoratet (2011). Retningslinjer for utforming av læereplaner for fag. Oslo: Utdanningsdirektoratet. Lest 07.08.2015, http://www.udir.no/globalassets/upload/larerplaner/lareplangrupper/retningslinjer_utf orming_lp_2012.pdf

Utdanningsdirektoratet (2017). Utdanningsdirektoratet.no. Lest 26.03.2017, https://www.udir.no/laring-og-trivsel/lareplanverket/finn-lareplan/

Wadel, C. (2007). Den samfunnsvitenskapelige konstruksjon av virkeligheten (3.utg.). Kristiansand: Høyskoleforlaget 